\title{
ENTRE A FORMA E O CONTEÚDO NA DESCONSTITUIÇÃO DOS NEGÓCIOS JURÍDICOS
}

\author{
BETWEEN THE FORM AND THE CONTENT IN THE PROCESS OF DISREGARD OF LEGAL \\ BUSINESS
}

\section{Paulo de Barros Carvalho}

\begin{abstract}
Resumo:
O estudo tem por objeto a chamada desconsideração do negócio jurídico praticada pelo Fisco em razão da dita interpretação econômica do direito. Trata o tema sob a perspectiva da dicotomia forma e conteúdo, procurando vislumbrar, no sistema do direito positivo, os mecanismos admitidos para promover a prevalência de uma forma contratual sobre a outra.

Palavras chave: Forma e conteúdo. Desconsideração de negócios jurídicos. Planejamento tributário.

Abstract:

The study's purpose is the so called disregard of legal business practiced by tax authorities on account of so-called law and economics method of interpretation. It approaches from the perspective of the form and content dichotomy, seeking for the law prescribed mechanisms to promote the prevalence of one contractual form over another.
\end{abstract}

Keywords: Form and content. Disregard of legal business. Tax planning.

\section{Introdução}

Antes de ingressar, propriamente, no assunto, entendo serem oportunas algumas palavras sobre o modo e por quais caminhos pretendo aproximar-me do objeto, para que seja possível articular suas complexidades, refletir sobre elas e poder, ao fim, construir conclusões consistentes capazes de acalmar o espírito instigado pela dúvida.

De fato, todo trabalho com aspirações mais sérias há de expor previamente seu método, assim entendido o conjunto de técnicas utilizadas pelo analista para demarcar o objeto, colocando-o como foco temático e, de seguida, construir o conteúdo. Parece apropriado efetuar breves considerações sobre o itinerário do pensamento, no sentido de abrir caminho para que o leitor possa percorrê-lo com desenvoltura, consciente do plano traçado pelo autor. A informação, que é de grande utilidade até para ensejar a iterativa conferência do rigor expositivo, volta-se, fundamentalmente, para esclarecer o trajeto que vai ser trilhado, facilitando sobremaneira a fundamentação das proposições apresentadas.

Professor emérito e titular da Pontifícia Universidade Católica de São Paulo - PUC-SP e da Universıdade de São Paulo - USP. Membro da Academia Brasileira de Filosofia. 
Tomarei o direito positivo como objeto cultural que se apresenta como camada de linguagem em função prescritiva, projetando-se sobre o domínio das condutas intersubjetivas, para regulá-las com seus operadores deônticos (permitido, obrigatório e proibido). Tais reflexões pedem a atenção para o modo pelo qual se opera a construção do sentido, interpretação do direito posto.

Para apropriada compreensão do tema, releva tecer alguns comentários sobre a função da linguagem na constituição da realidade jurídica. É importante também dedicar parte da atenção à dicotomia forma e conteúdo, que tem ocupado importante espaço nas discussões sobre a desconsideração de negócios jurídicos "simulados" Além disso, essa ordem de considerações nos levará à conclusão de que somente o fato qualificado como jurídico pode ser tomado para fins de determinar a formação do liame tributário, sendo descabidas análises de ordem meramente econômica.

Com suporte em tais premissas, e tendo em vista o princípio da autonomia da vontade e da livre iniciativa, aliada aos cânones da estrita legalidade e da tipicidade tributária, voltarei a atenção à possibilidade de o contribuinte praticar fatos que lhe acarretem menor ônus tributário. Somente nos casos de simulação, com a prática de atos fraudulentos e dolosos, ter-se-á a possibilidade de o Fisco desconsiderar os negócios praticados, fazendo recair a tributação sobre a forma negocial oculta (dissimulado). Examinarei, desse modo, a figura da simulação, traçando os pontos configuradores desta.

É assim que, firmando premissas na análise do direito positivo, encaminharei o raciocínio para estruturar respostas às indagações que me foram oferecidas.

\section{Conhecimento e linguagem}

Decompondo-se o fenômeno do conhecimento, encontramos o dado da linguagem, sem o qual ele não se fixa nem se transmite. Já existe um quantum de conhecimento na percepção, mas ele se realiza mesmo, na plenitude, no plano proposicional e, portanto, com a intervenção da linguagem. "Conhecer", ainda que experimente mais de uma acepção, significa "saber proposições sobre" Conheço determinado objeto se posso expedir enunciados sobre ele, de tal arte que o conhecimento, nesse caso, se manifesta pela linguagem, mediante proposições descritivas ou indicativas.

Por outro lado, a cada momento confirma-se a natureza da linguagem como constitutiva de nossa realidade. Já afirmava Wittgenstein, na proposição 5.6 do Tractatus Logico-Philosophicus, que "os limites da minha linguagem são os limites do meu mundo" significando: meu mundo vai até aonde for minha linguagem. A experiência o comprova: olhando para uma folha de laranjeira, um botânico seria capaz de escrever laudas, relatando a "realidade" que vê, ao passo que o leigo ficaria limitado a poucas linhas. Dirigindo o olhar para uma radiografia de pulmão, o médico poderia sacar múltiplas e importantes informações, enquanto o advogado, tanto no primeiro caso, como neste último, ver-se- 
ia compelido a oferecer registros ligeiros e superficiais. Por seu turno, examinando um fragmento do Texto Constitucional brasileiro, um engenheiro não lograria mais do que construir mensagem adstrita à fórmula literal utilizada pelo legislador, enquanto o bacharel em Direito estaria em condições para desenvolver análise ampla, contextual, trazendo à tona o conteúdo das normas jurídicas, identificando valores e apontando princípios. Por que alguns têm acesso a esses campos e outros não? Por que alguns ingressam em certos setores do mundo, ao mesmo tempo em que outros se acham absolutamente impedidos de fazê-lo? A resposta é uma só: a realidade do botânico, com relação à Botânica, é bem mais abrangente do que a de outros profissionais, o mesmo ocorrendo com a realidade do médico, do engenheiro e do bacharel em Direito. O fator determinante para que essas realidades se expandissem, dilatando o domínio dos respectivos conhecimentos, é a linguagem ou a morada do ser, como proclamou Heidegger.

O laço que prende um termo a seu significado costuma apresentar-se aos nossos olhos como algo dado a nós, um vínculo natural conhecido como elemento da realidade. Todavia, essa relação entre a palavra e a coisa é artificial. Quando aprendemos o nome de um objeto, não aprendemos algo acerca da coisa, senão sobre os costumes linguísticos de certo grupo ou povo que fala o idioma no qual esse nome corresponde a um específico objeto. Não obstante seja corriqueiro afirmar-se que uma coisa tem nome, seria mais rigoroso dizer que nós é que temos um nome para essa coisa. Disso decorre uma conclusão necessária: não existem nomes verdadeiros ou falsos. Há, tão somente, nomes aceitos ou não aceitos. A possibilidade mesma de inventar nomes, por sua vez, também leva um nome: liberdade de estipulação. Nesse sentido, asseveram Guibourg, Ghigliani e Guarinoni, ${ }^{1}$ cheios de convicção:

\begin{abstract}
Estas consideraciones nos llevan a una nueva conclusión, más profunda que la anterior: al inventar nombres (o al aceptar los ya inventados) trazamos límites en la realidad, como se la cortáramos idealmente en trozos; y al asignar cada nombre constituimos (es decir, identificamos, individualizamos, delimitamos) el trozo que, según hemos decidido, corresponderá a ese nombre. (...) Por esto la realidad se nos presenta ya cortada en trozos, como una pizza dividida en porciones, y no se nos ocurre que nosotros podríamos haber cortado las porciones de otro tamaño o con otra forma.
\end{abstract}

Decididamente, é também a linguagem que nos dá os fatos do mundo físico e do social. Feita a observação, verifica-se que o homem vai criando novos nomes e novos fatos, na conformidade de seus interesses e de suas necessidades. Para nós, basta uma só palavra para designar "neve" Para os esquimós, entretanto, envolvidos por circunstâncias

Introducción al conocimiento cientifico, Buenos Aires: EUDEBA, 1985, p. 37. 
bem diversas, impõe-se a distinção entre as várias modalidades de "neve" e a cada uma corresponderá um termo. Não se pode precisar o motivo exato, mas os povos de cultura portuguesa houveram por bem, em determinado momento de sua evolução histórica, especificar a palavra "saudade", diferentemente de outras culturas que a mantêm incluída em conceitos mais gerais, como "nostalgia" "tristeza" etc. Em português, como em castelhano, temos "relógio" ("reloj"); já em inglês discriminou-se "clock" para o relógio de parede e "watch" para o de bolso ou de pulso. E, em francês, existem três vocábulos distintos: "horloge" (de torre ou de parede), "pendule" (de mesa ou de pé) e "montre" (de bolso ou de pulso).

O esclarecimento das razões determinantes dessas especificações é, muitas vezes, encontrado na Gramática Histórica, disciplina incumbida de estudar as dinâmicas que presidem a evolução do idioma. A observação revela que tanto as palavras recémcriadas como as novas acepções atribuídas àqueles termos já conhecidos, incorporam-se ao patrimônio linguístico por força de necessidades sociais. A Física tinha no átomo a unidade irredutível da matéria. Com o progresso do interesse científico e o avanço das pesquisa que culminou com a possibilidade de decomposição daquela partícula, tornouse imperiosa a expansão da linguagem para constituir a nova realidade: eis o "próton". o "nêutron" o "elétron"

Breve comparação entre dicionários de um mesmo idioma, editados em momentos históricos diferentes, aponta para significativo crescimento do número de palavras, assim na chamada "linguagem natural" como nos discursos das várias ciências. É a linguagem constituindo realidades novas e alargando as fronteiras do nosso conhecimento.

\subsection{A constituição da "realidade jurídica" por meio da linguagem}

A linguagem natural está para a realidade em que vivemos assim como a linguagem do direito está para a nossa realidade jurídica. Dito de outra maneira, da mesma forma que a linguagem natural constitui o mundo circundante, por nós chamado de realidade, a linguagem do direito cria o domínio do jurídico, isto é, o campo material das condutas intersubjetivas, dentro do qual nascem, vivem e morrem as relações disciplinadas pelo direito. Se não há fato sem articulação de linguagem, também inexistirá fato jurídico sem a linguagem específica que o relate como tal. Se, por exemplo, S' empresta quantia em dinheiro para S", mas não consegue expressar sua reivindicação mediante as provas prescritas pelo direito como ajustadas à espécie, vale dizer, faltando a linguagem jurídica competente para narrar o acontecimento, não se poderá falar em fato jurídico. A circunstância conserva sua natureza factual porque descrita em linguagem ordinária, porém não alcança a dignidade de fato jurídico por ausência da expressão verbal adequada. 
O direito positivo é vertido em linguagem técnica, assim entendida toda aquela que se assenta no discurso natural, aproveitando, em quantidade considerável, palavras e expressões de cunho determinado, pertinentes ao patrimônio das comunicações científicas. Projeta-se sobre o campo do social, disciplinando os comportamentos interpessoais com seus três operadores deônticos (obrigatório, proibido e permitido), orientando as condutas em direção aos valores que a sociedade quer ver implantados. Sua função é eminentemente prescritiva, incidindo como um conjunto de ordens, de comandos, produzidos com o intuito de alterar comportamentos sociais, motivando seus destinatários.

Em termos de ação direta, é a linguagem do direito posto que constitui as realidades do mundo jurídico. Mesmo quando mal aplicadas, as regras do direito operam em nome do ordenamento em vigor, recortando-se o mundo social na estrita conformidade das determinações contidas nos seus comandos. Eis o fato meramente social adquirindo a dimensão de fato jurídico. Foi juridicizado, na expressão empregada por Pontes de Miranda, e, nesse momento, constituiu-se uma situação nova, ampliando a realidade do direito pela ação de sua linguagem própria.

3. Interpretação dos fatos: definição de "fato puro" "fato contábil" e "fato jurídico"

Feitas as necessárias considerações sobre a relevância da linguagem prescritiva do direito na constituição da realidade jurídica, convém discorrer sobre assunto de grande atualidade: os contornos constitutivos do fato jurídico tributário. O fato que dá causa a uma relação jurídica pode ser objeto de qualificações não-jurídicas? Em outras palavras, o fato, antecedente da norma jurídica individual e concreta, pode ser entendido como fato econômico, fato contábil, fato político ou mesmo fato histórico? É o que iremos examinar. Adianto, porém, que no contexto jurídico, só tem cabimento falar-se em elementos juridicizados, sendo inadmissível pretender atribuir efeitos de direito a fatos meramente econômicos, contábeis, políticos ou históricos.

Retornemos da digressão para considerar que, no degrau da hermenêutica jurídica, o grande desafio de quem pretende manifestar o conteúdo, sentido e alcance das regras de direito radica na inafastável dicotomia entre a letra da lei e a natureza do fenômeno jurídico subjacente. O desprestígio da chamada interpretação literaldispensa meditações mais profundas, bastando recordar que, prevalecendo como método de interpretação do direito, seríamos forçados a admitir estarem os meramente alfabetizados, quem sabe com o auxílio de um dicionário de tecnologia jurídica, credenciados a outorgar substância às mensagens legisladas, explicitando as proporções de significado da lei. O reconhecimento de tal possibilidade subtrairia à Hermenêutica Jurídica e à Ciência do Direito todo o teor de suas conquistas, relegando o ensino universitário a um esforço sem expressão e sentido prático de existência. Talvez por isso, e sem o perceber, Carlos Maximiliano haja 
sufragado, com suficiente ênfase, a validade de todos os métodos interpretativos desde que seus resultados coincidam com aqueles colhidos na interpretação sistemática.

Não sobeja repetir: para mim, as normas jurídicas são as significações que a leitura do texto desperta em nosso espírito e, nem sempre, coincidem com os artigos nos quais o legislador distribui a matéria no campo escrito da lei. Transmitido de outra maneira, na realidade social em que vivemos, experimentamos sensações visuais, auditivas, tácteis, capazes de suscitar noções. Estas, agrupadas em nosso intelecto, fazem surgir os juízos ou pensamentos que, por sua vez, se exprimem verbalmente como proposições. A proposição aparece como o enunciado de um juízo, da mesma maneira que o termo expressa uma ideia ou noção. A norma jurídica apresenta-se à experiência como proposição articulada dos termos encontrados nos textos de direito positivo. Ou seja, é resultado de um juízo que escolhe e ordena as ideias numa estrutura complexa. Um termo qualquer somente poderá receber o qualificativo jurídico quando integre desses juízos formadores de norma jurídica e, com isso, já posso afirmar que não há noção jurídica fora de norma.

Quer isto exprimir, por outros torneios, que a única forma de se entender o fenômeno jurídico, conclusivamente, é analisando-o como um sistema, visualizado no entrelaçamento vertical e horizontal dos inumeráveis preceitos que se congregam e se aglutinam para disciplinar o comportamento do ser humano, no convívio com seus semelhantes. O texto escrito, na singela expressão de seus símbolos, não pode ser mais do que a porta de entrada para o processo de apreensão da vontade da lei, jamais confundida com a intenção do legislador. Sem nos darmos conta, adentramos a análise do sistema normativo sob o enfoque semioticista, recortando, como sugere uma análise mais séria, a realidade jurídica em seus diferentes campos cognoscitivos: sintático, semântico e pragmático.

Bem sabido que não se pode priorizar qualquer das dimensões semióticas, em detrimento das demais. Todavia, o momento semântico, num exame mais apurado sobre o tema ora tratado, chama a atenção pela maneira intensa como qualifica e determina as questões submetidas ao processo dialógico que prepara a decisão ou conclusão. Daí exclamar Alfredo Augusto Becker, cheio de força retórica, ser o jurista nada mais que o semântico da linguagem do direito. A ele cabe a árdua tarefa de examinar os textos, quantas vezes obscuros, contraditórios, penetrados de erros e imperfeições terminológicas, para captar a essência dos institutos, surpreendendo, com nitidez, a função da regra, no implexo quadro normativo.

No processo de cognição da linguagem prescritiva de condutas, o hermeneuta esbarra em numerosos entraves que a realidade jurídica mesma lhe impõe. O primeiro obstáculo está cravado na própria matriz do direito. A produção das normas de mais elevada hierarquia no sistema, que são gerais e abstratas, está confiada aos parlamentos, casas legislativas de natural heterogeneidade, na medida em que se pretendam 
democráticas e representativas. Com isso, a despeito dos esforços na elaboração de uma linguagem técnica, dotada da racionalidade suficiente para atingir padrões satisfatórios de eficácia social, a verdade é que a mensagem legislada quase sempre vem penetrada de imperfeições, com problemas de ordem sintática e semântica, tornando muitas vezes difícil sua compreensão pelos sujeitos destinatários. É neste ponto que a Dogmática (Ciência do Direito em sentido estrito) cumpre papel de extrema relevância, compondo os enunciados frequentemente dispersos em vários corpos legislativos, ajeitando-os na estrutura lógica compatível e apontando as correções semânticas sugeridas pela leitura contextual. Com tais ponderações, a comunicação normativa flui mais facilmente do emissor ao receptor, realizando os propósitos da regulação jurídica com mais clareza e determinação.

Num segundo momento, depara-se o estudioso com uma realidade juridicamente complexa. Analisando no contexto de uma visão sistemática, onde as unidades normativas se entreligam formando uma estrutura sintática; onde há, inequivocamente, um referente semântico consubstanciado pela região material das condutas, ponto de confluência das iniciativas reguladoras do comportamento intersubjetivo; e onde se verificam as inesgotáveis manifestações dos fatores pragmáticos. Tudo isso, repito, traz ao estudo do fenômeno jurídico complexidades imensas. Na qualidade de exegeta, deve partir da literalidade do texto, e buscar as significações sistêmicas, aquelas que retratam os específicos parâmetros instituídos pelo sistema. Do mesmo modo, a consistência material das regras há de encontrar fundamento no sistema, sob pena de não prevalecerem, vindo a ser desconstituídas. Daí a tendência para cortar cerce o problema, ofertando soluções simplistas e descomprometidas, como ocorre, por exemplo, com a canhestra "interpretação literal" das formulações normativas, que leva consigo a doce ilusão segundo a qual as regras do direito podem ser isoladas do sistema e, analisadas na sua compostura frásica, desde logo "compreendidas" Vê-se o jurista, portanto, na contingência de consultar diversos preceitos de um diploma e, até, a sair dele, fazendo incursões pelo sistema.

Por fim, não nos esqueçamos de que a camada linguística do direito está imersa na complexidade do tecido social, cortada apenas para efeito de aproximação cognoscitiva. O real, com a multiplicidade de suas determinações, só é suscetível de uma representação intuitiva, porém aberta para receber inúmeros recortes cognoscitivos. Com tais ponderações, torna-se hialina a afirmativa de que a partir de um mesmo evento, poderá o jurista construir o fato jurídico; como também o contabilista, o fato contábil; e o economista o fato econômico. Tudo, portanto, sob a dependência do corte que se deseja promover daquele evento.

E quanto ao âmbito de compreensão desse fenômeno, retornando à linha de raciocínio inicial, citemos que todos os fatos são construções de linguagem, e, como tanto, são representações metafóricas do próprio evento. Seguem a gramaticalidade própria do universo linguístico a que pertencem, o jurídico, quando constituinte do fato jurídico, 
ou o contábil, por exemplo, quando construtora do fato contábil. As regras da gramática cumprem função linguística reguladora de um idioma historicamente dado. Prescrevem a forma de combinação dos vocábulos e das expressões para produzirmos oração, isto é, construção com sentido daquele universo linguisticamente dado. O direito, portanto, é linguagem própria compositiva de uma realidade jurídica. Provém daí o nominar-se Gramática Jurídica ao subconjunto das regras que estabelecem como outras regras devem ser postas, modificadas ou extintas, dentro de certo sistema.

Posto isso, perceberemos que a construção do fato jurídico nada mais é que a constituição de um fraseado normativo capaz de justapor-se como antecedente normativo de uma norma individual e concreta, dentro das regras sintáticas ditadas pela gramática do direito, assim como de acordo com os limites semânticos arquitetados pela hipótese da norma geral e abstrata.

Há que ter em mente, nesse caminho, uma importante informação: as palavras componentes desta frase constitutiva de realidade jurídica têm uma denotação, apontam o conjunto dos significados que, posteriormente, representam o signo. Ao mesmo tempo, essas palavras classificam-se dicotomicamente, na medida em que estabelecem duas categorias: a dos objetos representados e a dos objetos não representados.

Tal ocorre com a expressão fato jurídico. Tem-se como certo, nos dias de hoje, que o conhecimento científico do fenômeno social, seja ele qual for, advém da experiência, aparecendo sempre como uma síntese necessariamente a posteriori. $\mathrm{Na}$ constituição do fato jurídico, a análise relacional entre a linguagem social e a linguagem jurídica, redutora da primeira, sobrepõe-se a esse conhecimento sinzetético, obtendo como resultado um novo signo, individualizado no tempo e no espaço do direito e recebendo qualificação jurídica: eis o fato jurídico. É, portanto, uma construção de sobrelinguagem. Há duas sínteses: (i) do fenômeno social ao fenômeno abstrato jurídico e (ii) do fenômeno abstrato jurídico ao fenômeno concreto jurídico.

Adotados esses pressupostos, verificaremos que o termo ou expressão que adquirir o qualificativo "jurídico" não somente será representativo de uma unidade do universo do direito, como também denotará seu contraponto, isto é, todos os outros fatos linguisticamente possíveis de serem construídos a partir daquele mesmo evento, mas que não se enquadram às regras sintáticas e semanticamente dadas pelo sistema de linguagem do direito. A demarcação do objeto implica a delimitação do corte de sua classe e, ao traçar esses limites o exegeta obtém como resultado indireto a formação do conjunto dos fatos que não se qualificam como tal. Trata-se de singela construção resultante da lógica, pois, no universo das proposições normativas, "p" (proposição) é diferente e oposto de "n-p" (não-proposição), impedindo a quem se dispõe a conhecer o sistema incluir a classe "n-p" dentro do conjunto "p" São categorias que tomam o mesmo universo, mas não se entrecruzam. Ou seja, de um mesmo evento pode-se construir um fato jurídico ou um fato 
contábil; mas um e outro são sobremaneira diferentes, isso impede de inscrever o último como antecedente da norma individual e concreta, dado que representa unidade carente de significação jurídica. O fato capaz de implicar o consequente normativo haverá de ser sempre fato jurídico, mesmo que muitas vezes haja situações nas quais num e noutro estejam presentes os mesmos conteúdos denotativos. A partir desses dados é que poderemos demarcar o conjunto dos fatos jurídicos, separando-o do conjunto dos fatos não-jurídicos, onde se demoram os fatos econômicos, os fatos contábeis, os fatos históricos e tantos outros quantas sejam as ciências que os constroem. O critério utilizado para a separação desses dois domínios é justamente a homogeneidade sintática do universo jurídico.

Com tais considerações, cabe relembrar que todo conhecimento do objeto requer cortes e mais recortes científicos, cuja função é simplificar a complexa realidade existencial, delimitando o campo da análise. Não nos esqueçamos de que a camada linguística do direito está imersa na complexidade do tecido social, cortada apenas para efeito de aproximação cognoscitiva. O direito positivo é objeto do mundo da cultura e, como tal, torna árdua a tarefa do exegeta em construir a plenitude de seus conteúdos de significação, obrigando-o a reduzir a complexidade empírica, ora isolando ora selecionando caracteres do dinâmico mundo do existencial. O objeto passa a ser uma construção em linguagem feita pelo intérprete ao reduzir as características próprias e imanentes daquilo que se toma do universo físico-social.

Eis uma barreira intransponível à concepção do "fato puro" seja ele econômico, histórico, político, jurídico ou de qualquer outra qualidade que se lhe pretenda atribuir. Tais fatos, como acrescenta Lourival Vilanova ${ }^{2}$, são elaborações conceptuais, subprodutos de técnicas de depuração de ideias seletivamente ordenadas.

Pelo exposto, fica a ressalva de que não há fatos jurídicos puros ou fatos econômicos puros. Existem cortes de linguagem. Nós, juristas, montamos a realidade jurídica que representa o corte. Desta maneira, construímos a interpretação jurídica. Nada disso impede que economistas tomem a mesma base objetiva e produzam enunciados econômicos sobre ela. Produzem-se, por sua vez, outros cortes sobre o mesmo acontecimento, compondo novo signo. E a mesma coisa ocorre para o historiador, que constitui o fato histórico; para o sociólogo, que constrói o fato sociológico, entre tantos outros recortes que se possam produzir naquela realidade. À confusão metodológica que se estabelece no instante do corte Becker chamou de "mancebia irregular" do direito tributário com outras Ciências. Aliás, foi precisamente pela pretensão de fixar como objeto a atividade financeira do Estado, passando a examiná-la sob todos os ângulos possíveis e imaginários, sem qualquer prioridade metodológica, que a Ciência das Finanças

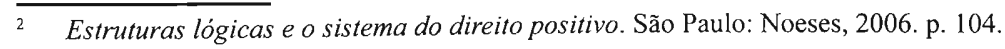


rotundamente faliu, não mais existindo como disciplina nas grades curriculares das Faculdades de Direito do Brasil.

Discorrendo acerca do modo de pensar algumas vezes irrefletido da doutrina tradicional, também conhecida como "doutrina bem comportada do Direito Tributário" Alfredo Augusto esclarece:

Exemplo de carência de atitude mental jurídica é a divulgadíssima tese (aceita como coisa óbvia) que afirma ser a hipótese de incidência ("fato gerador", "fato imponível", "suporte fáctico") sempre um fato econômico. Outro exemplo atual é a muito propagada doutrina da interpretação e aplicação do Direito Tributário segundo a "realidade econômica do fenômeno social" Como se demonstrará, ambas as teorias têm como resultado a demolição da juridicidade do Direito Tributário e a gestação de um ser híbrido e teratológico: o Direito Tributário invertebrado. ${ }^{3}$

No âmbito dessas investigações, chegaremos à conclusão de que os fatos, assim como toda construção de linguagem, podem ser observados como jurídicos, econômicos, antropológicos, históricos, políticos, contábeis, etc.; tudo dependendo do critério adotado pelo corte metodológico empreendido. Existe interpretação econômica do fato? Sim, para os economistas. Existirá interpretação contábil do fato? Certamente, para o contabilista. No entanto, uma vez assumido o critério jurídico, o fato será, única e exclusivamente, fato jurídico; e claro, fato de natureza jurídica, não econômica ou contábil, entre outras matérias. Como já anotado, o direito não pede emprestado conceitos de fatos para outras disciplinas. Ele mesmo constrói sua realidade, seu objeto, suas categorias e unidades de significação.

\section{Forma e conteúdo}

Que é o conteúdo de algo? Aquele que se depare com a pergunta: que é a federação brasileira, poderia muito bem responder à indagação com a frase "A República Federativa do Brasil é formada pela união indissolúvel dos Estados e Municípios e do Distrito Federal" sob o manto da Constituição (art. $1^{\circ}$ da CR). Eis o conteúdo, diria. Mas mesmo essa frase, terá ela também seu suporte físico, suas marcas de tinta no papel (ou até mesmo pontos luminosos numa tela de computador) que a encerram numa forma. E não pode ser diferente: não há maneira de ser senão por uma forma.

Precisas e rigorosas as palavras do professor Lourival Vilanova: ${ }^{4}$

Teoria geral do direito tributário. 4. ed.. São Paulo, Marcial Pons/Noeses, 2007. p. 17 (grifos do autor). o poder de julgar e a norma. In: ESCRITOS Jurídicos Filosóficos. São Paulo: IBET/Axis Mundi, 2003. v. 1., p. 358 . 
[...] Não há vida sem sê-lo em forma. Já o corpo é a forma-limite, que contrapõe o ser vivente ao seu contorno. Pouco importa que seja a mais rudimentar espécie de vida biológica: há sempre um contorno próprio, em face do mundo circundante. Sem isso, não seria de um microcosmos imerso dentro do macrocosmos. A vida social não escapa a essa congênita presença da forma. Apenas há um pluralismo de formas modeladoras da existência social. O direito pré-político, ou a sociedade juridicamente sem Estado é, historicamente, a protoforma. Depois, vem o Estado e dá-se a politização do direito, forma mais potente para conter a multiplicação dos fatores sociais.

A prevalência do conteúdo sobre a forma é mais um dentre os falsos problemas que perturbam a compreensão do direito positivo. Isso porque forma e conteúdo longe de serem aspectos separáveis a ponto de um preterir o outro, são dimensões de um objeto incindível. Com propriedade, o escritor e crítico literário José Veríssimo observou: "a forma é o fundo aparecendo". E não há outro modo de conhecer, descer às entranhas do significado para atribuir-lhe significação, senão pelo contato com a forma com que se apresente o signo.

A expressão de São Paulo "a letra mata, mas o espírito vivifica" 5 longe de refutar o argumento reforça a importância da forma. Inexiste outro meio de travar contato com o objeto senão a forma, porquanto, diante dela, não bastará a aproximação pela intuição sensível: é preciso que exista esforço do sujeito cognoscente para apreendê-lo e, assim, vivificá-lo em seu espírito. Quer dizer, com outras palavras: é necessário interpretar a forma para outorgar-lhe conteúdo.

O conhecimento somente se faz presente quando exteriorizado e, para que possa romper as fronteiras do mundo intrasubjetivo, objetivando-se, tornar-se-á imprescindível exprimir o sabido. Vertendo-o numa forma.

Ao atribuir conteúdo, dá-se vida à forma e pela ação de interpretar, a forma passa a implicar um conteúdo. Mas forma a que não se atribua conteúdo não pode aspirar ao status de signo, com o que o conteúdo, sempre que seja objeto de enunciação, também implica forma. Insta dizer então: num signo qualquer, forma e conteúdo co-existem e, mais ainda, se co-implicam.

A forma é, a um só tempo, a porta que nos dá acesso ao plano do conteúdo e também é a saída para o domínio da intersubjetividade. Um dicionário, por exemplo, ao explicitar o conteúdo de uma palavra qualquer, não tem outro meio de fazê-lo senão pelo emprego de outros termos, indubitavelmente formas para outros conteúdos. Assim também o fez o Poder Constituinte ao grafar já no art. $1^{\circ}$ uma definição de Federação. Tanto na

2 Coríntios 3:6. 
definição lexical de um verbete, como naquela estipulativa do direito, vê-se logo que o conteúdo de um signo somente pode fazer-se aparente - intersubjetivo - pelo emprego de outro signo e, com isso, mostram-se forma e conteúdo unidos, inseparavelmente.

Insisto que ao definir um conceito qualquer, não se produz somente conteúdo, estar-se-á diante de uma forma, porque sem ela não é possível aproximar do objeto. Assim a aporia "forma e conteúdo" mostra-se, em verdade, relação entre uma e outra forma. É forma o termo "república federativa" como também o é sua definição no art. $1^{\circ}$ da Constituição da República. E da mesma natureza é o cotejo da forma produzida em uma alteração de contrato ou estatuto social de uma sociedade empresarial com aquela outra que diz o Fisco ser a "substância econômica do negócio"

Se há situações em que as formas se põem em acordo mútuo, como no caso das definições (mesmo aquelas chamadas estipulativas), haverá ocasiões em um domínio linguístico nas quais se verifique o conflito. Nesses casos, é necessário que existam regras do próprio sistema para orientar a decisão do interprete sempre que da divergência resultar a dúvida sobre qual deva prevalecer.

5. O subsistema constitucional tributário e os princípios que orientam a atividade interpretativa: estrita legalidade e tipicidade tributária

O conceito de sistema incide em todas as regiões ônticas: no mundo dos objetos naturais, ideais, metafísicos e culturais. Falamos em sistema nervoso, sistema solar, sistema social, sistema jurídico e outros mais. Aquele que particularmente nos interessa é o sistema jurídico, locução referente tanto ao direito positivo quanto à Ciência que o descreve.

Da concepção global de sistema jurídico-positivo, tomada a expressão como conjunto de normas associadas segundo critérios de organização prescritiva, e todas elas voltadas para o campo material das condutas interpessoais, extraímos o subsistema das normas constitucionais e, dentro dele, outro subsistema, qual seja o subsistema constitucional tributário. Pode dizer-se, ainda que em traços largos e sobremodo abrangentes, serem suas unidades integrantes as normas constitucionais relacionadas, direta ou indiretamente, à matéria tributária.

O subsistema do qual falamos é fortemente marcado por enunciados de cunho axiológico, revelando a orientação do legislador constituinte em impregnar as normas de inferior hierarquia com uma série de conteúdos de preferência por núcleos significativos.

O primeiro é o cânone da legalidade, projetando-se sobre todos os domínios do direito e inserido no art. $5^{\circ} \mathrm{II}$, do Texto Constitucional vigente: "ninguém será obrigado a fazer ou deixar de fazer alguma coisa senão em virtude de lei" No setor do direito tributário, porém, esse imperativo ganha feição de maior severidade, por força 
do que se conclui da leitura do art. 150, I, do mesmo diploma: "sem prejuízo de outras garantias asseguradas ao contribuinte, é vedado à União, aos Estados, ao Distrito Federal e aos Municípios: I - exigir ou aumentar tributo sem lei que o estabeleça" Em outras palavras, qualquer das pessoas políticas de direito constitucional interno somente poderá instituir tributos, isto é, prescrever a regra-matriz de incidência, ou aumentar os existentes, majorando a base de cálculo ou a alíquota, mediante expedição de lei.

Quadra advertir que a mensagem não é dirigida somente ao legislador das normas gerais e abstratas, mas, igualmente, ao administrador público, ao juiz e a todos aqueles a quem incumba cumprir ou fazer cumprir a lei. No desempenho das respectivas funções, a todos se volta o mandamento constitucional, que há de ser cumprido. Qualquer tipo de imposição tributária há de curvar-se aos ditames desse primado, conquista secular dos povos civilizados que permanece como barreira intransponível para os apetites arrecadatórios do Estado-Administração.

O mesmo cabe dizer das demais regras impositivas de comportamentos aos contribuintes. Em linha de princípio, o veículo introdutor da norma tributária no ordenamento há de ser sempre a lei (sentido lato). O princípio da estrita legalidade, todavia, vem acrescer os rigores procedimentais em matéria de tributo, dizendo mais: estabelece que a lei adventícia traga, no seu bojo, os elementos descritores do fato jurídico e os dados prescritores da relação obrigacional. Esse plus caracteriza a tipicidade tributária.

Tipicidade tributária significa a exata adequação do fato à norma, e, por isso mesmo, o surgimento da obrigação se condicionará ao evento da subsunção, que é a plena correspondência entre o fato jurídico tributário e a hipótese de incidência, fazendo surgir a obrigação correspondente, nos exatos termos previstos em lei. Não se verificando o perfeito quadramento do fato à norma, inexistirá obrigação tributária. Nesse percurso, ou ocorre a subsunção do evento relatado à regra, ou não ocorre, afastando-se terceira possibilidade. Perfaz-se aqui a eficácia da lei lógica do terceiro excluído: a proposição "p" é verdadeira ou falsa, inadmitindo-se situação intermediária. Por outro lado, ocorrido o fato, a relação obrigacional que nasce há de ser exatamente aquela estipulada no consequente normativo.

Em síntese: sem lei anterior que descreva o fato imponível, não nasce obrigação tributária (princípio da legalidade); sem subsunção do evento descrito à hipótese normativa, também não surge obrigação tributária (princípio da tipicidade); e havendo previsão legal e a correspondente subsunção do fato à norma, os elementos do liame jurídico irradiado devem equivaler àqueles prescritos na lei (princípio da tipicidade). São condições necessárias para o estabelecimento de vínculo tributário válido. O desrespeito a esses cânones fulminará, decisivamente, qualquer pretensão de cunho tributário. 


\subsection{Comentários adicionais acerca da tipicidade e do caráter vinculado da tributação}

Como já anotei, o exercício do poder impositivo-fiscal, no Brasil, encontrase orientado por uma série de diretrizes, dirigidas especialmente para organizar as relações que nesse setor se estabelecem. São os chamados "princípios constitucionais tributários" na maioria explícitos, e aos quais deve submeter-se a legislação infraconstitucional, quando o tema da elaboração normativa seja a instituição, administração e cobrança de tributos. Pois bem, entre tais comandos, em posição de indiscutível preeminência, situase o princípio da tipicidade tributária, definido como a estrita necessidade de que a lei adventícia traga no seu bojo, de maneira expressa e inequívoca, os elementos descritores do fato jurídico e os dados prescritores da relação obrigacional.

A aplicação do princípio exige, como se verifica, que os agentes da Administração, no exercício de suas funções de gestão tributária, indiquem, pormenorizadamente, todos os elementos do tipo normativo existentes na concreção do fato, além dos traços jurídicos característicos da conduta ilícita.

De outra parte, o princípio da vinculabilidade da tributação, recortado do Texto Supremo e inserido no art. 142 do Código Tributário Nacional, traduz uma conquista no campo da segurança dos administrados, em face dos poderes do Estado Moderno, de tal forma que o exercício da administração tributária encontra-se tolhido, em qualquer de seus movimentos, pela necessidade de aderência total aos termos inequívocos da lei, não podendo abrigar qualquer resíduo de subjetividade própria dos atos de competência discricionária.

Por isso é que no procedimento administrativo de gestão tributária não se permite ao funcionário da Fazenda o emprego de recursos imaginativos. Para tanto, a mesma lei reguladora do gravame, juntamente com outros diplomas que regem a atividade administrativa, oferece um quadro expressivo de providências, com expedientes das mais variadas espécies, tudo com o escopo de possibilitar a correta fiscalização do cumprimento das obrigações e deveres estatuídos.

É imprescindível que os agentes da Administração, incumbidos da constituição do vínculo tributário, ao relatarem o fato jurídico, demonstrem-no por meio de linguagem admitida pelo direito. Assim se diz que as provas da ocorrência factual devem ser aptas para certificar a ocorrência do evento narrado: comprovar a legitimidade da norma individual e concreta que documenta a incidência tributária significa promover a verificação de que o acontecimento fáctico narrado e a relação jurídica instaurada mantêm estrita correspondência com as provas montadas e apresentadas mediante formas linguísticas selecionadas pelo direito positivo. 


\section{O princípio da autonomia da vontade}

No exercício da atividade de fiscalização, compete à autoridade administrativa investigar os fatos ocorridos, colhendo, com observância às regras pertinentes ao direito das provas, elementos que possibilitem a formulação de juízo quanto à incidência das normas tributárias. Ao desempenhar tal função, porém, deve ater-se a apurar os fatos praticados, averiguando se estes preenchem as linhas definitórias circunscritas na hipótese normativa: havendo o perfeito enquadramento, nasce a obrigação tributária, mediante seu relato na linguagem prevista pelo direito positivo; existindo algum ponto dissonante, a percussão jurídica fica obstada.

As considerações acima formuladas são de extrema relevância, pois em virtude do princípio da autonomia da vontade, que viceja no âmbito do Direito Privado, pode o particular adotar as mais variadas estruturas negociais. Para atingir o resultado econômico pretendido, está habilitado a escolher livremente o arcabouço negocial que melhor lhe aprouver, de forma que os custos sejam reduzidos e os lucros multiplicados.

A título de exemplo, são inegavelmente lícitas as atitudes dos contribuintes que objetivem à reestruturação e reorganização de seus negócios. A própria Constituição da República, ao garantir o direito de propriedade (art. $5^{\circ}, \mathrm{XXII}$ ) e o pleno direito ao exercício da autonomia da vontade (art. 5\% IV, IX, XIII, XV e XVII; e art. 170 e seus incisos), dentre os quais se encontra a liberdade contratual, confere ao contribuinte a permissão para ordenar-se do modo que entender mais vantajoso, segundo o princípio da livre iniciativa.

Consignadas tais anotações, impõe-se o registro segundo o qual, prevendo a norma tributária, em sua hipótese, "tipo estrutural" somente poderá ser aplicada com a ocorrência do negócio jurídico nela previsto. A prática de negócio jurídico diverso, ainda que permita atingir resultado econômico parecido, não autoriza à autoridade administrativa lavrar o lançamento, constituindo crédito tributário. A supremacia da segurança jurídica nas relações entre Estado e indivíduo determina a tendência conceptual classificatória no Direito Tributário, representada pelo princípio da tipicidade cerrada, impedindo a juridicização de fatos outros que não aqueles estipulados no antecedente da regra-matriz de incidência.

A opção negocial feita pelo contribuinte, para melhor operacionalizar o desempenho de suas atividades, não pode ser desconsiderada pela autoridade administrativa, para fins de tributação. O desprezo pela forma adotada encontra óbice intransponível na legalidade tributária e na tipicidade fechada.

Ademais, como já insistia Alfredo Augusto Becker, ${ }^{6}$

6 op. cit., p. 130. 
[...] a doutrina da Interpretação do Direito Tributário, segundo a realidade econômica, é filha do maior equívoco que tem impedido o Direito Tributário de evoluir como ciência jurídica. Esta doutrina, inconscientemente, nega a utilidade do direito, porquanto destrói precisamente o que há de jurídico dentro do Direito Tributário.

Em face da taxatividade da tipologia tributária, à autoridade administrativa não resta espaço para valoração econômica acerca dos negócios praticados. O tipo estrutural exige, para que se efetue a subsunção, que a parcela da realidade a qual se pretende tributar corresponda à exata qualificação jurídica prevista na hipótese normativa. Se, em virtude dos princípios da autonomia da vontade e da livre iniciativa, o fato for reputado, pelo Direito Privado, como diverso daquele descrito no antecedente da regra-matriz, não há que se falar em surgimento da obrigação tributária. Inadmissível a desconsideração das formas adotadas pelo particular para, usando critérios meramente econômicos, sujeitá-lo, à tributação, como se diversa fosse a forma negocial por ele praticada

\section{A figura da "Simulação" no Direito brasileiro}

Uma coisa é eleger forma menos onerosa para o desempenho, pelo particular, de suas atividades. Outra, bem diferente, é agir com malícia, no intuito de prejudicar terceiros. Enquanto na primeira hipótese tem-se ato lícito, cuja desconsideração é inconcebível, a segunda encontra-se no campo da ilicitude, sendo repudiada pelo ordenamento jurídico.

O Código Civil, ao regular o assunto, dispôs no art. $167, \S 1^{\circ}$ sobre as hipóteses em que se considera simulado o negócio jurídico:
$\S 1^{\circ}$ Haverá simulação nos negócios jurídicos quando:
I aparentarem conferir ou transmitir direitos a pessoas diversas daquelas às quais realmente se conferem, ou transmitem;
II contiverem declaração, confissão, condição ou cláusula não verdadeira;
III - os instrumentos particulares forem antedatados, ou pós- datados.

"Simular" significa disfarçar uma realidade jurídica, encobrindo outra que é efetivamente praticada. Nas palavras de Marcos Bernardes de Mello,

o que caracteriza a simulação é, precisamente, o ser nãoverdadeira, intencionalmente, a declaração de vontade. $\mathrm{Na}$

7 Teoria do fato jurídico: plano da validade. 2. ed. São Paulo: Saraiva, 1997. p. 153. 
simulação quer-se o que não aparece, não se querendo o que efetivamente aparece.

Além disso, para que o ocultamento da realidade seja considerado um defeito, é imprescindível haver intenção de prejudicar terceiros ou de violar disposição de lei, isto é, dolo.

A simulação é, em síntese, uma declaração enganosa da vontade, visando a produzir efeito diverso daquele que a declaração real da vontade acarretaria. Nas palavras de Orlando Gomes ${ }^{8}$, ocorre a simulação quando "em um negócio jurídico se verifica intencional divergência entre a vontade real e a vontade declarada, com o fim de enganar terceiros" No negócio simulado, as partes fingem um negócio que na realidade não desejam.

Aplicando esses conceitos ao campo do Direito Tributário, conclui-se que os atos tendentes a ocultar ocorrência de fato jurídico tributário configuram operações simuladas, pois não obstante a intenção consista na prática do fato que acarretará o nascimento da obrigação de pagar tributo, este, ao ser concretizado, é mascarado para que aparente algo diverso do negócio praticado pelas partes.

Por outro lado, a celebração de negócio jurídico válido, cuja escolha decorre da autonomia da vontade e livre iniciativa do particular, implicando a ausência de subsunção do fato à norma tributária ou acarretando o quadramento à norma tributária que prescreva exigências menos onerosas, é perfeitamente lícita e não susceptível de desconsideração pela autoridade administrativa. Isso porque, como tenho reiteradamente afirmado, a realidade jurídica é constituída pelo próprio direito: este prevê a forma e a linguagem a ser adotada para que se tenha determinado fato ou não. Dessa maneira, havendo preferência por certa forma, é inaceitável que esta seja ignorada pela simples razão de seu resultado econômico vir a ser semelhante ao de outra forma, diferençadamente tributada.

Pelo exposto, depreende-se que, tendo a obrigação tributária nascimento apenas se e quando ocorrido o fato previsto na hipótese normativa, quaisquer atos do contribuinte que impliquem a verificação de fato distinto daquele previsto pela legislação tributária impedirão, também, o surgimento da respectiva obrigação. Esse modo de agir é lícito, não podendo ser ignorado pelo Fisco. Tão-só na hipótese de, já ocorrido o fato jurídico tributário, vir este a ser ocultado, mediante atos simulados, é que a fiscalização estará diante de autênticas "operações simuladas" susceptíveis de serem desconhecidas para fins de tributação e imposição de penalidades.

Apenas as operações do contribuinte que mascarem determinada transação jurídica, ocultando, por formas artificiosas, a realidade do direito, configuram "operações simuladas" Sucede, por exemplo, quando o comerciante registra a venda da mercadoria

8 Introdução ao estudo do direito. 7. ed. Rio de Janeiro: Forense, 1983. p. 374. 
por uma quantia inferior àquela realmente cobrada, objetivando reduzir o montante do ICMS a ser pago, ou quando as partes, ao firmarem contrato, fixam remuneração em valor inferior àquele acordado, com vistas a omitir receitas. Em ambos os casos, há duas formas: uma aparente, outra dolosamente oculta.

Para que haja simulação é necessário, portanto: (i) conluio entre as partes; (ii) divergência entre a forma do negócio praticado pelas partes e a forma do negócio por elas declarado; e (iii) intenção de lograr o Fisco.

Se não houver prova de qualquer desvio jurídico na declaração de vontade dos partícipes, ela é real, verdadeira e efetiva, condizente, portanto, com o negócio pactuado pelas partes. Forma e conteúdo são juridicamente adequados. Inexiste, para o Direito, o objetivo de burlar o Fisco e ocultar a ocorrência de fato jurídico tributário, mas a finalidade de praticar negócios lícitos em perfeita harmonia com os interesses dos sujeitos envolvidos.

7.1 Interpretação dos atos praticados pelo contribuinte -ilicitude como requisito para desconsideração do negócio jurídico

A interpretação dos negócios jurídicos, bem como os efeitos deles decorrentes, há de ser feita segundo as prescrições do direito posto. E a legislação brasileira não admite sobreposição do conteúdo econômico em relação à forma. Mesmo porque o conteúdo econômico é ele uma forma, recortada do contínuo da realidade social segundo critérios próprios da ciência econômica e não de acordo com os traços apontados pelo direito positivo como aptos à produção de efeitos na realidade jurídica. Apenas uma forma jurídica pode se sobrepor a outra e tão somente quando o direito assim o determinar. Se lícito o ato, não pode ele ser desconsiderado pela autoridade administrativa, com o tão só argumento de que implicaria menor carga tributária.

Sem dúvida, é legítima a técnica de organização preventiva dos negócios jurídicos a serem praticados, visando à economia de tributos. Com maior razão, é admissível a realização de atos que, além da redução de carga tributária, venham revestidos de propósito negocial.

A Lei Complementar n. 104/2001 acrescentou o parágrafo único ao art. 116 do Código Tributário Nacional, dispondo que "a autoridade administrativa poderá desconsiderar atos ou negócios jurídicos praticados com a finalidade de dissimular a ocorrência do fato gerador do tributo ou a natureza dos elementos constitutivos da obrigação tributária, observados os procedimentos a serem estabelecidos em lei ordinária" É de ver que referido preceito não introduziu alteração alguma no ordenamento brasileiro, uma vez que este já autorizava a desconsideração de negócios jurídicos dissimulados, a exemplo do disposto no art. 149, VII, do Código Tributário Nacional. 
O enunciado acima transcrito veio apenas a ratificar regra existente no direito pátrio. Todavia, necessário se faz enfatizar a recomendação acerca do cuidado que se deve ter para não ampliar demasiadamente a aplicação do comentado parágrafo único, vindo a considerar dissimulado negócio jurídico lícito, pelo simples fato de acarretar vantagens de ordem tributária. Neste último caso, as partes celebram negócio que, não obstante importe redução ou eliminação da carga tributária, é legal e, dessa maneira, válido, diferentemente dos atos dissimulados, consistentes na ilegal ocultação da ocorrência do fato jurídico tributário. O parágrafo único do art. 116 do Código Tributário Nacional não veio para impedir negócios tendentes a redução de carga tributária; nem poderia fazê-lo, pois o contribuinte é livre para escolher o ato que pretende realizar, acarretando, conforme sua escolha, o nascimento ou não de determinada obrigação tributária.

Demais disso, em face do princípio da estrita legalidade e da tipicidade fechada, que já foram objeto de análise em tópico anterior, somente haverá tributação se o fato concretizado guardar quadramento com a hipótese da regra-matriz de incidência. Consequentemente, apenas os atos fraudulentos, praticados com o único intuito de ocultar o verdadeiro negócio efetivado, mascarando o fato jurídico, são suscetíveis de desconsideração pela autoridade fiscal, com a correspondente lavratura do auto de infração. É o que prescreve expressamente a legislação brasileira, a qual, ao delimitar o conceito de simulação, exige a presença do dolo e a prática de ilícitos.

Vejamos o que dispõem os arts. 71,72 e 73 da Lei n. 4.502/64, que disciplinam as figuras da sonegação, fraude e conluio:

Art. 71. Sonegação é toda ação ou omissão dolosa tendente a impedir ou retardar, total ou parcialmente, o conhecimento por parte da autoridade fazendária:

I - da ocorrência do fato gerador da obrigação tributária principal, sua natureza ou circunstâncias materiais;

II - das condições pessoais de contribuinte, suscetíveis de afetar a obrigação tributária principal ou o crédito tributário correspondente.

Art. 72. Fraude é toda ação ou omissão dolosa tendente a impedir ou retardar, total ou parcialmente, a ocorrência do fato gerador da obrigação tributária principal, ou a excluir ou modificar as suas características essenciais, de modo a reduzir o montante do imposto devido, a evitar ou a diferir seu pagamento.

Art. 73. Conluio é o ajuste doloso entre duas ou mais pessoas naturais ou jurídicas, visando qualquer dos efeitos referidos nos arts. 71 e 72 .

Nota-se que as figuras da sonegação e da fraude estão relacionadas com a ocultação da realidade: pratica-se ato ensejador o nascimento da obrigação tributária, mas impede-se o Fisco de tomar conhecimento do pactuado, seja mediante condutas mascaradoras do negócio realizado (simulação), seja por meio de atitudes que, ilicitamente, 
modifiquem ou excluam os caracteres do fato (fraude). O conluio, por sua vez, caracterizase exatamente pelo acordo entre duas ou mais pessoas, com vistas a concretizar atos simulatórios ou fraudulentos.

Para que seja admissível a autuação fiscal, desconsiderando o negócio jurídico praticado, não basta serem os efeitos econômicos de tal prática semelhantes aos de ato diverso, mas passível de tributação. É imprescindível que tenha havido ilicitude em tal realização, nos exatos termos dos arts. 71, 72 e 73, acima transcritos.

\subsection{Imprescindibilidade do elemento subjetivo "dolo" para configurar simulação}

Tomadas as infrações tributárias na sua extensa generalidade, podemos fixar o critério da participação subjetiva do agente na descrição hipotética da norma e classificá-las em (i) infrações subjetivas e (ii) infrações objetivas. Para que as primeiras se configurem, faz-se necessário que a lei exija do autor do ilícito o haver operado com dolo ou culpa, esta, em qualquer de suas três modalidades. No que atina às objetivas, a singela ausência do elemento volitivo na composição da hipótese normativa já denuncia sua presença. Nestas últimas, não é preciso apurar o comportamento subjetivo do agente ao realizar o ilícito: tenha ele pretendido o resultado ou assumido o risco de produzilo, tenha descurado dos efeitos de sua conduta, procedendo com negligência, imperícia ou imprudência, ou, finalmente, se nada aconteceu, mas o resultado se verificou concretamente, basta para se definir o vulto jurídico da infração objetiva.

Ainda que o princípio geral, no campo das infrações tributárias, seja o da responsabilidade objetiva, o legislador não está tolhido de criar figuras típicas de ilícitos subjetivos. São elas a sonegação, a fraude e o conluio, além daquelas em que se elege a culpa como ingrediente necessário do tipo legal, aplicando-se penalidade mais severa, exatamente em virtude da presença do elemento subjetivo. Para que se configure a fraude, o agente deve atuar de maneira dolosa. Consequentemente, identificado esse ilícito, a multa é agravada, dado o repúdio com que são tratadas as figuras onde o infrator age com intenção de se locupletar indevidamente, em prejuízo do Erário.

A distinção entre infrações objetivas e subjetivas abre espaço à larga aplicação prática. Tratando-se das primeiras, o único recurso de que dispõe o suposto autor do ilícito, para defender-se, é concentrar razões no sentido de demonstrar a inexistência material do fato acoimado de antijurídico, descaracterizando-o em qualquer de seus elementos constituintes. Agora, no setor das infrações subjetivas, em que penetram o dolo ou a culpa na compostura do enunciado descritivo do fato ilícito, a situação inverte-se, competindo à autoridade administrativa, com toda a gama instrumental dos seus expedientes, exibir os fundamentos concretos reveladores da presença do dolo ou da culpa, como nexo entre a participação do agente e o resultado material que dessa forma se produziu. Os embaraços dessa comprovação, nem sempre fácil, incumbem ao acusador, a quem o sistema atribui 
a tarefa intransferível de evidenciar não só a materialidade do evento, como, também, a presença inafastável do elemento volitivo que propiciou ao infrator atingir seus fins contrários às disposições da ordem jurídica vigente.

É com base em tais argumentos que se predica a inadmissibilidade das presunções no que tange às infrações subjetivas. No direito brasileiro, dolo e culpa não se presumem: provam-se.

8. Requisitos para a realização do lançamento e para a aplicação das sanções em face de operações simuladas: existência de provas

No hemisfério do direito, o uso competente da linguagem pressupõe a manipulação adequada dos seus signos e, em especial, a simbologia que diz respeito às provas, isto é, à técnica que o direito elegeu para articular os enunciados fáticos com os quais opera. De ver está que o discurso prescritivo do direito posto indica, fato por fato, os instrumentos credenciados para constituí-los, assim os acontecimentos do mundo social que não puderem ser relatados com tais ferramentas de linguagem não ingressam nos domínios do direito, por mais evidentes que sejam.

Para que possa o Fisco constituir a nova forma que pretende ver prevalecer sobre aquela do contribuinte, deve empregar os meios probatórios aptos a constituir tanto o fato jurídico tributário que entende ter sido oculto, como também o fato jurídico da simulação. São esses os requisitos postos pelo direito positivo. Somente com a demonstração da evidente intenção de fraudar é que será possível desencadear as normas previstas pela legislação para coibir as práticas de burla à legislação fiscal. Vale, nesse caso, reiterar a afirmação: não se admitem presunções ou suposições no tocante à configuração de fraude, dolo e simulação, pois são atos que dependem da vontade do agente.

Convém anotar que durante muitos anos foi admitida a tese segundo a qual o ônus da prova, em matéria fiscal, era incumbência do contribuinte. Com a evolução da doutrina, nos dias de hoje, não se apregoa mais a inversão da prova por força da presunção de legitimidade dos atos administrativos e tampouco se pensa que esse atributo exonera a Administração de provar as ocorrências cujas existências são afirmadas. Na própria configuração oficial do lançamento, a lei institui a necessidade de que o ato jurídico administrativo seja devidamente fundamentado, significando dizer que o Fisco tem de oferecer prova concludente da ocorrência do evento em estrita conformidade da previsão genérica da hipótese normativa. Seguindo adiante, vindo o sujeito passivo contestar a fundamentação do ato aplicativo lavrado pelo Fisco, o ônus de exibir a improcedência dessa iniciativa impugnatória volta a ser, novamente, da Fazenda, a quem competirá provar o descabimento jurídico da impugnação, fazendo remanescer a exigência. Vê-se, no fundo, que é função precípua do Estado-Administração empregar a linguagem jurídica competente na produção dos atos de gestão tributária. O pressuposto de fato da incidência 
há de ser relatado de maneira transparente e cristalina, com suporte nas provas admissíveis nesse setor do direito, para que possa prevalecer, surtindo os efeitos de estilo, quais sejam os de constituir o vínculo da obrigação, atrelando o particular ao Fisco, em termos da satisfação do objeto prestacional.

Supor que um fato tenha acontecido ou que sua materialidade tenha sido efetivada, porém, não é o mesmo que exibir a concretude de sua existência, mediante prova, conferindo-lhe segurança e certeza. Esse o motivo por que, no Direito Tributário, os recursos à presunção devem ser utilizados com muito e especial cuidado. Nesse subdomínio jurídico, não deve a presunção ser concernente aos aspectos estruturados da norma de incidência tributária.

Se levarmos em consideração os valores máximos abrangidos por nosso Texto Constitucional, principalmente em termos de tributação, que respaldam os cânones da legalidade e da tipicidade, torna-se extremamente problemático captar a figura da presunção, sempre fértil para suscitar imprecisão, dubiedade e incerteza.

$O$ indício não é suficiente para acarretar a presunção da ocorrência de determinado fato, sendo apenas o pretexto jurídico que autoriza a pesquisa, na busca das provas necessárias. Juridicamente verificados os indícios, servirão eles de ponto de partida para a procura daquilo que se chama "verdade dos fatos" o que há de ser efetivado mediante a utilização dos meios de prova em direito admitidos. $O$ caminho seguro que os agentes do Poder Tributante devem seguir, no sentido de manter-se dentro dos parâmetros do sistema constitucional tributário brasileiro, aponta para o afastamento de hipóteses presuntivas, tanto quando diga respeito ao acontecimento do fato jurídico como nas situações de infrações tributárias.

No procedimento administrativo de gestão tributária, é imprescindível a cabal demonstração de causalidade entre o fato observado, considerado como indício, e a efetiva existência do ato infrator. Em outras palavras, não pode haver sombra de dúvida sobre a concreção do fato que dá causa à autuação administrativa, sendo inadmissível adotar a figura da presunção, tendo em vista que esta consiste no processo lógico em que de um fato conhecido infere-se fato desconhecido e, portanto, incerto.

\section{Considerações finais}

Traçadas algumas ideias que considero de grande importância para o tema, julgo ter demonstrado que a dicotomia entre forma e conteúdo não pode ser resolvida com a prevalência de um sobre o outro.

A cada domínio de linguagem há de corresponder a forma que lhe seja própria e capaz de explicitar os conteúdos relevantes segundo as regras de combinação e seleção dos signos para a formação dos enunciados. Também assim no direito, que deve valer-se das regras adequadas à construção de seus fatos, desprezando tudo quanto não foi 
juridicizado. Mostra-se, dessa maneira, inadequado o emprego de técnicas como aquela interpretação econômica do direito.

Quero dizer também que todo tipo é, também ele, uma forma, assim também a norma esquematizada na Regra-Matriz de Incidência Tributária. Quadrar aquilo que foi vertido em linguagem numa forma ou em outra forma é fazer nova operação de subsunção, submetendo-se a todos os requisitos existentes para tanto e outros mais, sem os quais não pode a nova forma substituir a primeira.

Que faz o contribuinte ao estruturar seu negócio? Uma forma. Que faz o Fisco ao reduzir a termo sua pretensão de "desconstituir" o negócio jurídico produzido pelo contribuinte? Impor-lhe outra forma. Como decidir o conflito entre essas formas? Há regras no sistema que prevêem tais possibilidades: o princípio da autonomia da vontade privada desempenha aí papel fundamental, mas que comporta suas exceções, em especial a figura da simulação. Afora essas situações é vedado à Administração apontar a forma negocial como diversa daquela escolhida pelo sujeito.

São Paulo, 28 de fevereiro de 2011.

\section{Referências}

BECKER, Alfredo Augusto. Teoria geral do direito tributário. 4. ed. São Paulo: Marcial Pons/ Noeses, 2007.

GOMES, Orlando. Introdução ao estudo do direito. 7. ed. Rio de Janeiro: Forense, 1983.

GUIBOURG, R. et al. Introducción al conocimiento científico. Buenos Aires: EUDEBA, 1985.

MELLO, Marcos Bernardes de. Teoria do fato jurídico: plano da validade. 2. ed. São Paulo: Saraiva, 1997.

VILANOVA, Lourival. O poder de julgar e a norma. In: ESCRITOS Jurídico-Filosóficos. São Paulo: IBET/Axis Mundi. 2003. v. 1.

. Estruturas lógicas e o sistema do direito positivo. São Paulo: Noeses, 2006. 